\title{
KEBENARAN DAN PERANAN AL-QUR'AN DALAM KESEMPURNAAN SISTEM IMUN TUBUH MANUSIA
}

\author{
Rosydina Robi'aqolbi, dr., M.Kes. \\ Sekolah Tinggi Ilmu Al-Qur'an dan Sains Al-Ishlah (STIQSI) \\ Sendangagung Paciran Lamongan \\ Email: rosydina.rq@alishlah.ac.id
}

\begin{abstract}
Abstrak
Al-Qur'an merupakan kitab yang tidak terbantahkan kebenarannya. Berbagai ilmuwan di seluruh belahan dunia tertarik untuk mengkaji secara ilmiah tentang bukti kebenaran firman Allah dalam kitab suci Al-Qur'an. Salah satu bukti kebenaran Al-Qur'an adalah kebenarannya ketika berbicara tentang kesempurnaan penciptaan manusia. Salah satu kesempurnaan ciptaan manusia yang begitu mengagumkan terdapat pada sistem imun tubuh manusia. Tulisan ini akan mengkaji melalui literature review bagaimana sempurnanya cara kerja sistem imun yang dimiliki oleh manusia dibandingkan dengan makhluk lainnya. Juga akan dibahas tentang peranan Al-Qur'an dalam meningkatkan imunitas tubuh manusia.
\end{abstract}

Kata kunci: Al-Qur'an, Imunitas, Manusia

\section{Pendahuluan}

Al-Qur'an tidak hanya kitab suci bagi umat muslim, tetapi juga merupakan wahyu terakhir yang diturunkan untuk seluruh umat manusia di dunia. Keajaibannya selalu terkuak dan terbukti secara ilmiah dengan banyaknya bukti penelitian tentang kebenaran Al-Qur'an. Ketika kitab-kitab lain disandingkan dengan Al-Qur'an dan telah gagal dibuktikan kebenarannya, Al-Qur'an yang sejak awal turun hingga saat ini masih terjaga kemurnian isinya, belum bisa terbantahkan kebenarannya.

Hingga saat ini, tidak sedikit para ilmuwan meneliti tentang isi Al-Qur'an dan membuktikannya dengan teori-teori ilmiah. Al-Qur'an tidak hanya memantik jiwa para pembacanya serta para huffadz saja, tetapi Al-Qur'an selalu menarik perhatian para ilmuwan dan para peneliti di berbagai bidang keilmuan, salah satunya bidang kedokteran.

Sistem imunitas tubuh manusia telah begitu gamblang dijabarkan teorinya saat ini, namun Al-Qur'an telah berabad-abad lebih dahulu mengemukakan bahwa 
manusia adalah sebaik-baik penciptaan. Seperti disebutkan dalam QS. At-Tiin ayat 4 yang berbunyi:

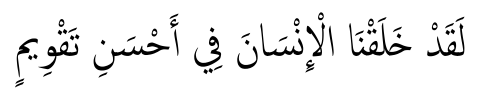

Makna dari ayat tersebut adalah "sesungguhnya kami telah menciptakan manusia dalam bentuk yang sebaik-baiknya"1

Dalam Tafsir Ibnu Katsir disebutkan bahwa inilah yang disumpahkan, Allah telah menciptakan manusia dengan bentuk yang paling baik dan membentuk pendirian yang kokoh, anggota tubuh yang sempurna dan mempercantiknya. ${ }^{2}$

Dalam Tafsir Al-Mukhtashar/Markaz Tafsir di bawah pengawasan Syaikh Dr. Shalih bin Abdullah bin Humaid, Imam Masjidil Haram, diterangkan bahwa Allah menciptakan manusia dengan tubuh yang tegak, sehingga dapat memakan makanannnya dengan tangan; dan Allah menciptakannya dengan kemampuan memahami, berbicara, mengatur, dan berbuat bijak, sehingga memungkinkannya menjadi khalifah di muka bumi sebagaimana yang Allah kehendaki. ${ }^{3}$

\section{Metodologi}

Tulisan ini ditulis dengan metodologi literature review, yakni dengan mencari sumber penafsiran ayat-ayat dalam al-Qur'an yang berhubungan dengan kesempurnaan penciptaan manusia dibandingkan makhluk lainnya, serta menggabungkan beberapa hasil penelitian atau pengamatan ilmiah tentang pengaruh Al-Qur'an terhadap sistem imun manusia.

\section{Perbedaan Sistem Imun Tubuh Manusia dengan Makhluk Lainnya}

Dibanding makhluk lainnya, manusia memiliki komponen dan struktur tubuh yang paling kompleks dan paling sempurna. Salah satu kesempurnaan kompenen tubuh manusia berada pada sistem pertahanan (imunitas) tubuhnya.

Perbedaan sistem imun antara tumbuhan dan hewan telah dikemukanan oleh Maekwa, dkk pada tahun 2011 dalam papernya. Keduanya memiliki persamaan

\footnotetext{
${ }^{1}$ QS. At-Tin (95): 4.

${ }^{2}$ Nasib Ar-Rifa'I (2012): Ringkasan Tafsir Ibnu Katsir Jilid 4. Jakarta: Gema Insani. 768.

${ }^{3}$ Tafsir Al-Mukhtashar/Markaz Tafsir di bawah pengawasan Syaikh Dr. Shalih bin Abdullah bin Humaid, Imam Masjidil Haram https://tafsirweb.com/12853-surat-at-tin-ayat-4.html diakses pada tanggal 3 Oktober 1989
} 


\section{Rosydina Robi'aqolbi}

ketika bereaksi terhadap patogen tetapi perbedaannya juga sangat penting dan mendasar. Baik tumbuhan dan hewan, keduanya memiliki pertahanan tubuh baik spesifik dan tidak spesifik, namun tumbuhan tidak memiliki pertahanan tubuh adaptif. ${ }^{4}$ Tumbuhan tidak memiliki limfosit dan sel memori seperti yang ada pada hewan ketika bereaksi terhadap benda asing, mikroba atau patogen lainnya. Tetapi tumbuhan memiliki system acquired resistance (SAR) sebagai pertahanan terhadap infeksi sekunder. ${ }^{5,6}$ Persamaan dan perbedaan sistem imun antara tumbuhan dan manusia berdasarkan imun spesifik dan non spesifik, systemic acquired resistance (memori imun), transgenerasi imun memori dan perubahan pada gen juga dijelaskan pada penelitian L. Kiraly, dkk. pada tahun $2013 .{ }^{7}$

Berbagai jenis hewan memiliki sistem imun tubuh yang berbeda-beda. Namun hewan yang memiliki sistem imunitas yang paling kompleks adalah vertebra. Bagian tubuh yang paling awal terpapar oleh patogen adalah permukaan tubuh dan organ-organ pencernaan. Hewan yang berbeda memiliki pertahanan tubuh yang berbeda, contohnya adalah ikan yang memiliki mukosa pada kulitnya dan juga pencernaannya, mukosanya mampu memompa IgM pada sel-sel epitelnya. ${ }^{8}$

Tikus merupakan hewan yang paling sering dijadikan model miniatur sistem imunitas manusia, sehingga tikuslah hewan yang sering dijadikan percobaan studi in vivo. Meskipun begitu, sistem imunitas tikus memiliki banyak perbedaan dengan yang dimiliki oleh manusia. Perbedaan tersebut memungkinkan adanya beberapa penelitian yang menyatakan bahwa sebuah terapi bisa berhasil diberikan pada tikus atau hewan percobaan lainnya, namun belum tentu bisa berhasil ketika diujicobakan kepada manusia. Beberapa perbedaan sistem imunitas tikus dan manusia baik sistem imun innate maupun adaptif yang dijabarkan oleh Javier

\footnotetext{
${ }^{4}$ Maekawa, t., Kufer, t. A. and schulze-Lefert, P. (2011): nLr functions in plant and animal immune systems: so far and yet so close. nature Immunol. 12, 818-826.

${ }^{5}$ Ross, A. f. (1961): systemic acquired resistance induced by localized virus infections in plants. Virology 14, 340-358.

${ }^{6}$ Durrant, W. e. and Dong, X. (2004): systemic acquired resistance. Annu. rev. Phytopathol. 42, 185-209.

${ }^{7}$ L.Kiraly, dkk. (2013): Similarities and Differences in Plant and Animal Immune Systems What is Inhibiting Pathogen? Acta Phytopathologica at Entomologica Hungarica 48 (2), 187-205.

${ }^{8}$ Bailey M (2011). The immune system: differences between man, pigs, ruminants and mice.. Front. Immunol. Conference Abstract: ECMIS - E. coli and the Mucosal Immune System : Interaction, Modulation and Vaccination. doi: 10.3389/conf.fimmu.2011.01.00003
} 
Mestas dan Chirstoper C.W. Huges tahun 2004 ada pada keseimbangan jumlah lukosit, Toll receptors, inducible NO synthase, reseptor inhibitori sel NK, sel B, sel $\mathrm{T}$, sel sitokin dan reseptor sitokin, sel $\mathrm{T}$ helper, sel endotel untuk mempresentasikan antigen- cemokin dan reseptor cemokin. ${ }^{9}$

\section{Sejarah Ditemukannya Teori Imunitas}

Ketika bicara tentang teori imunitas, maka nama yang tidak bisa dilepas dari sejarah adalah Edward Janner, seseorang yang hasil kerjanya dianggap sebagai dasar ilmu imunologi. Edward Janner berperan dalam menemukan cara memerangi penyakit cacar (smallpox). Penyakit yang muncul sejak sekitar 10.000 SM dan membunuh berjuta-juta orang dengan angka kematian 20-98\% bagi yang terinfeksi, qadarullah penyakit tersebut berakhir pada abad ke 19 M. Edward Jenner dikenal nyata di seluruh dunia atas kontribusinya dalam imunisasi dan pemberantasan smallpox dengan teknik vaksinasi. Meskipun sebenarnya teknik inokulasi (pemindahan mikroorganisme baik bakteri ataupun virus dari tempat atau sumber asalnya ke medium baru) ternyata berasal dari peradaban islam di zaman kekhalifahan Turky Ustmaniyah. ${ }^{10}$

Abu Bakr Muhammad Ibn Zakariya Al Razi (Rhazes) merupakan dokter muslim berkebangsaan Persia yang pada abad ke-9 atau kurang lebih seribu tahun sebelum dikenalnya teknik variolasi telah mendeskripsikan dengan jelas gejala dan tanda penyakit smallpox dalam bukunya yang berjudul al-Jadari wa al-Hasba (smallpox dan campak). Beliaulah orang yang pertama kali mencetuskan teori tentang "adaptive immunity" atau "acquired immunity" atau "specific immune system" atau "immunological memory". Beliau mengamati bahwa orang yang selamat dari penyakit smallpox tidak akan terkena penyakit tersebut untuk kedua kalinya seumur hidup. Sehingga penemuan tersebut menjadi cikal bakal lahirnya vaksin dengan cara membuat seseorang memiliki memori imunitas dengan memaparkan kuman atau virus tersebut. ${ }^{11}$

\footnotetext{
${ }^{9}$ Javier Mestas and Christopher C. W. Hughes (2004). Of Mice and Not Men: Differences between. J Immunol (172), 2731-2738.

${ }^{10}$ Saifudin, dkk. (2016): Islam, Sains, dan Kesehatan: Metode Islam dan Sains dalam Mengungkap Kebenaran. Yogyakarta: Pustaka Muslim. 103-107.

11 Khadan. (2016): Al Razi, Smallpox and Measles. http://www.muslimheritage.com/ article/al-raz-smallpox-and-measles (diakses 3 Oktober 2019).
} 


\section{Rosydina Robi'aqolbi}

\section{Cara Kerja Sistem Imun Tubuh Manusia}

Sistem imun merupakan sebuah sistem pertahanan tubuh untuk melindungi dari agen-agen mikroba patogen (sesuatu yang dapat menyebabkan penyakit), membantu melawan racun dan substansi alergenik yang masuk melalui permukaan tubuh dan mukosa tubuh. ${ }^{12}$

Imunitas merupakan kekebalan terhadap suatu penyakit, terutama penyakit infeksi. Sekumpulan sel, jaringan dan molekul yang menjadi mediasi kebalnya tubuh terhadap infeksi disebut sebagai sistem imun. Reaksi kumpulan sel dan molekul terhadap mikroba infeksius disebut respon imun. Sehingga imunologi diartikan sebagai sebuah ilmu yang mempelajari tentang sistem imun dan responnya terhadap suatu patogen. Fungsi fisiologis dari sistem imun adalah mencegah dan mengeradikasi infeksi. ${ }^{13}$

Peran penting dari sistem imun terhadap kesehatan tubuh sudah banyak digambarkan, sebagai contoh individu yang memiliki kekurangan respon imun terhadap infeksi yang serius bahkan mengancam nyawa seperti penyakit smallpox yang mematikan berjuta-juta orang selama ribuan tahun dan berhasil dieradikasi dengan proses vaksinasi. Dan sejak tahun 1980an penyakit yang berkembang dan belum ditemukan vaksinnya hingga saat ini adalah penyakit AIDS (acquired immunodeficiency syndrome). Respon imun merupakan sistem pertahanan tubuh terhadap suksesnya transplantasi organ sebagai terapi kegagalan suatu organ. Begitu juga terapi terhadap kanker yaitu dengan menstimulus respon imun terhadap sel kanker. Imunitas yang abnormal dapat menyebabkan penyakit yang serius hingga mematikan. ${ }^{13}$

Sistem pertahanan tubuh manusia terdiri dari innate/natural/naive/nonspecific dan adaptive/acquired/specific. Sistem imun innate menginisiasi perlindungan awal tubuh terhadap infeksi. Sementara sistem imun adaptive merupakan pertahanan tubuh ketika mikroba sudah mulai menginvasi jaringan seluler. Sehingga sistem imun adaptif ini terjadi ditingkat seluler. ${ }^{13}$

${ }^{12}$ David D. (2010): Overview of the Immune Response. J Allergy Clin Immunology., 125, 3 -

${ }^{13}$ Abbas Abul K, Andrew Lichtman. (2011): Basic Immunology, Function and Disorders of Immune System $3^{\text {rd }}$ Edition. Saunders, an imprint of Elsevier Inc. 
Sistem imun innate terdiri dari pertahanan fisik/mekanis (kulit, selaput lendir, silia, mekanisme batuk dan bersin), pertahanan larut (asam lambung, lisozim, laktoferin, asam neurominik, dll, komplemen, interferon, C-Reactive Protein/ CRP), pertahanan seluler terdiri dari fagosit (mononuklear atau monosit dan makrofag, polimorfonuklear/PMN atau neutrofil dan eosinophil), sel Nol (Natural Killer/NK, sel Killer/K), sel mediator (basophil, mastosit, trombosit). Sedangkan sistem imun adaptif terdiri dari sistem humoral yang terdiri atas sel B dan sistem seluler yang terdiri atas sel T (T helper $1 \& 2)$, Ts, Tdh, Tc. ${ }^{14}$

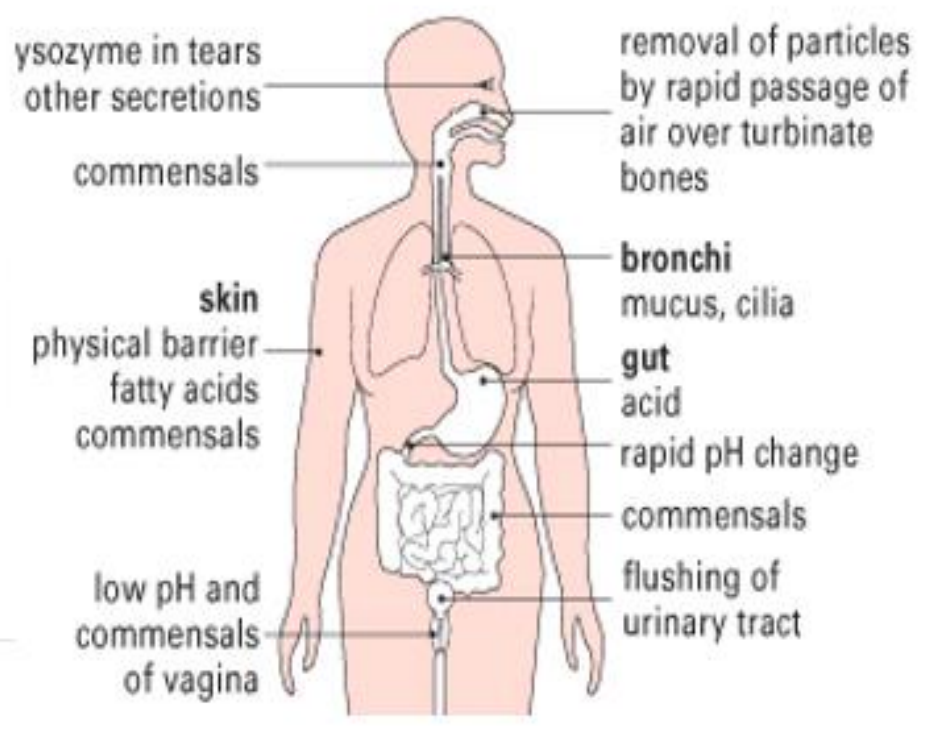

Immunobiology 7 ed. Gerland Sciece 2008

Kulit memiliki pertahanan sel epitel yang bisa mencegah masuknya kuman atau benda asing. Jika sel epitelnya rusak maka akan mudah dimasuki oleh kuman. Selain itu kulit juga memiliki tingkat keasaman yang dapat membuat bakteri tidak betah tinggal, antibacterial peptide, dan normal flora (bakteri nonpatogen). Lambung juga memiliki tingkat keasaman tinggi yang susah ditembus oleh bakteri, paru memiliki silia atau bulu-bulu kecil yang bergerak sehingga dapat menyapu kuman atau benda asing keluar tubuh melalui mekanisme batuk, bersin, dan kotoran yang keluar dari hidung. Mata memiliki enzim dan air mata yang dapat melindungi tubuh dari benda asing atau agen patogenik lainnya. ${ }^{15}$

\footnotetext{
${ }^{14}$ Karnen Ganna, Iris R. (1996): Imunologi Dasar Edisi 3, Jakarta: Balal Penerbit FKUI

${ }^{15}$ Kenneth Murphy, Paul Travers, and Mark Walport (2008): Janeway's Immunobiology $7^{\text {th }}$ ed. Garland Science, New York, NY, 2008.
} 


\section{Rosydina Robi'aqolbi}

Pada kedua sistem imun innate maupun adaptive memiliki tiga fase dalam mempertahankan tubuh dari mikroba patogen dan benda asing, pertama fase rekognisi dimana tubuh manusia mengurai produk-produk sistem imun, kedua fase aktivasi dimana sel-sel imun mengalami inflamasi, dan ketiga fase efektor yaitu fase menghilangkan agen patogen. ${ }^{15}$

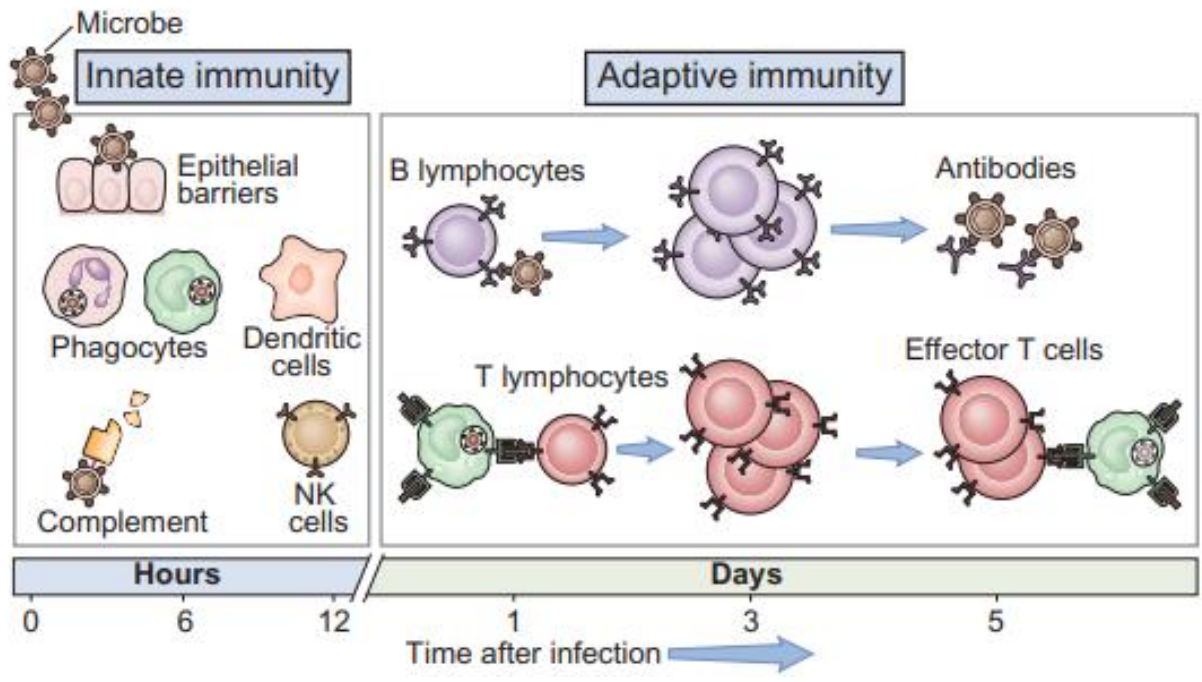

Abbas, 2011: Basic Immunology

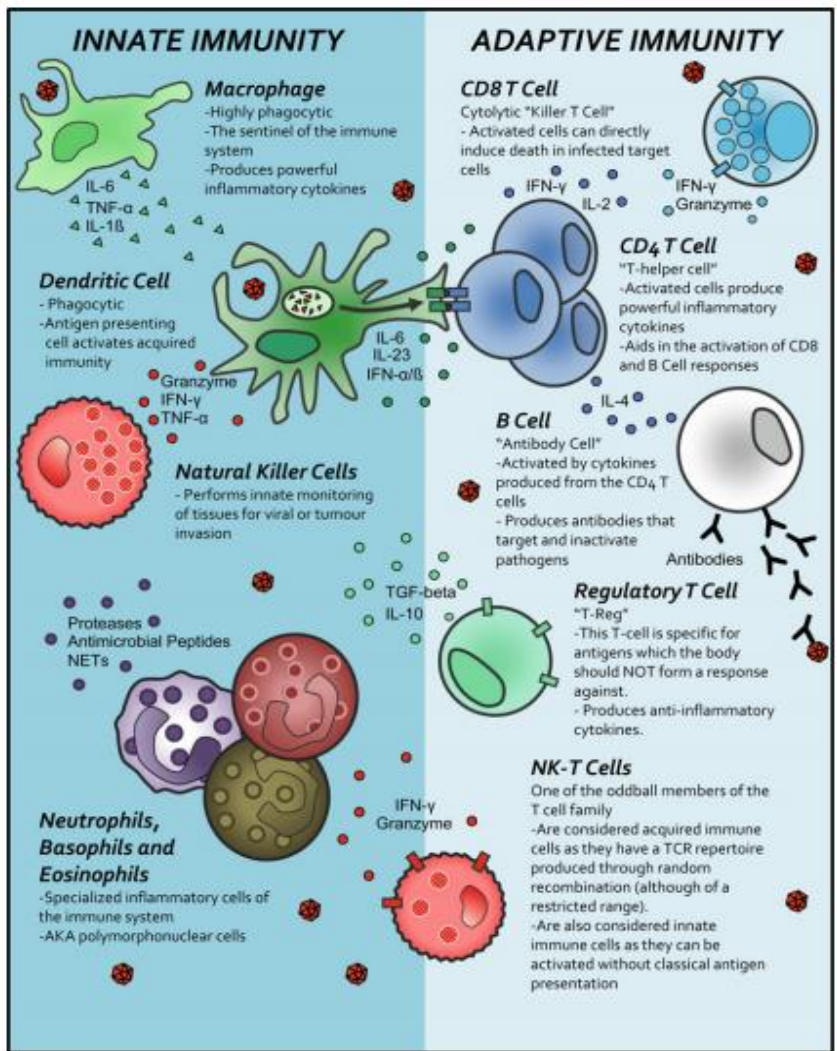


Scott McComb et al.2013. Introduction to Immune System.

Setelah kuman masuk ke dalam jaringan, maka mikroba patogen tersebut direkognisi atau dikenali oleh makrofag dari beberapa komponen dari bakteri tersebut, bisa dari dinding bakteri yang mengandung lipid (LPS), karbohidrat (manosa dan glukan) serta pathogen Associated Molecular Patterns (PAMPs). Ikatan yang terjadi antara bakteri ke makrofag menstimulasi proses fagositosis (makrofag menghancurkan kuman dengan cara memakannya).15

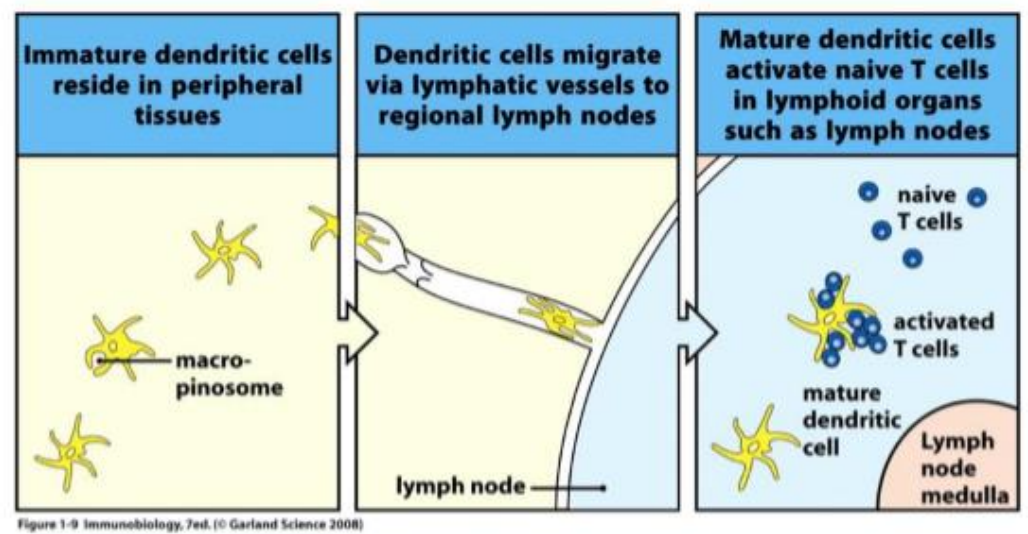

Setelah kuman difagosit oleh makrofag, kemudian makrofag menginisiasi sistem imun adaptive. Sel dendritik/makrofag yang sudah memfagosit kuman dikenali oleh sel $\mathrm{T}$ dari PAMPs yang dimiliki, kemudian dibawa masuk kedalam sistem limfatik dan sel B dalam sistem humoral (ekstrasel) mengeluarkan antibodi untuk melawan kuman di luar sel. Di dalam sel, sel T menstimulus makrofag untuk memfagosit kuman, jenis sel $\mathrm{T}$ lainnya yaitu sel $\mathrm{T}$ sitotoksik memiliki kemampuan menghancurkan kuman secara langsung, dan sel $\mathrm{T}$ helper membantu sel B bekerja. Tanda dari

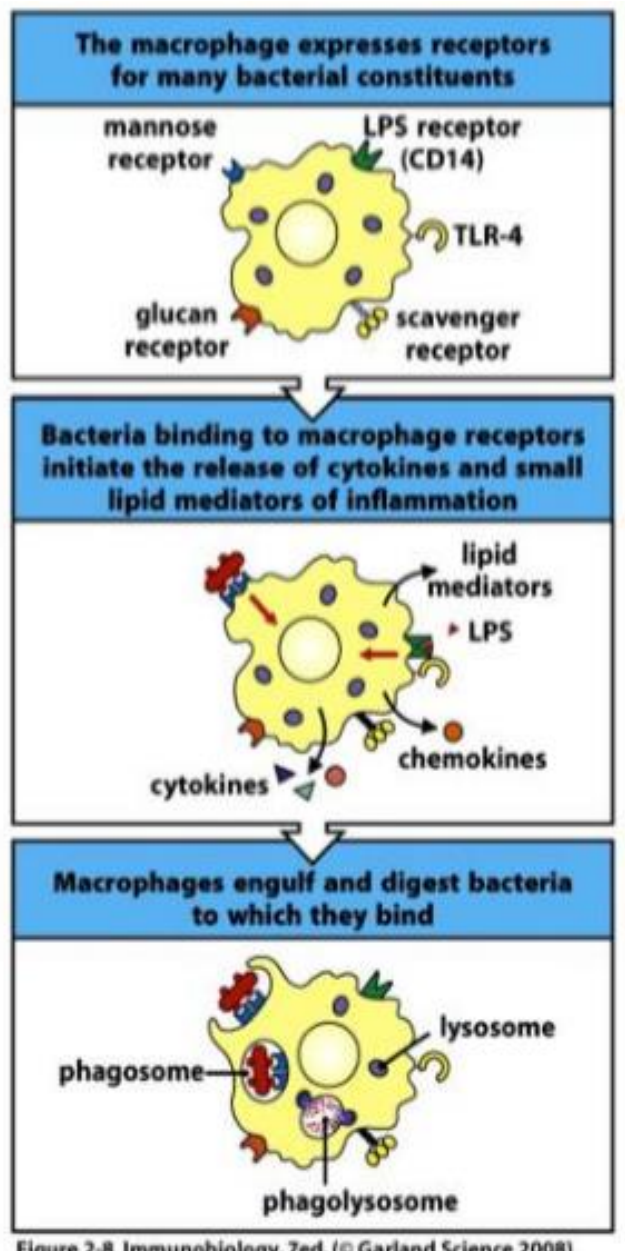




\section{Rosydina Robi'aqolbi}

imunitas adaptive adalah sel $\mathrm{T}$ dan sel B yang memiliki memori terhadap struktur setiap patogen yang pernah ditemui sehingga tubuh tidak akan memberi respon terhadap patogen yang sama berkali-kali seperti saat pertama kali terinfeksi. ${ }^{13}$

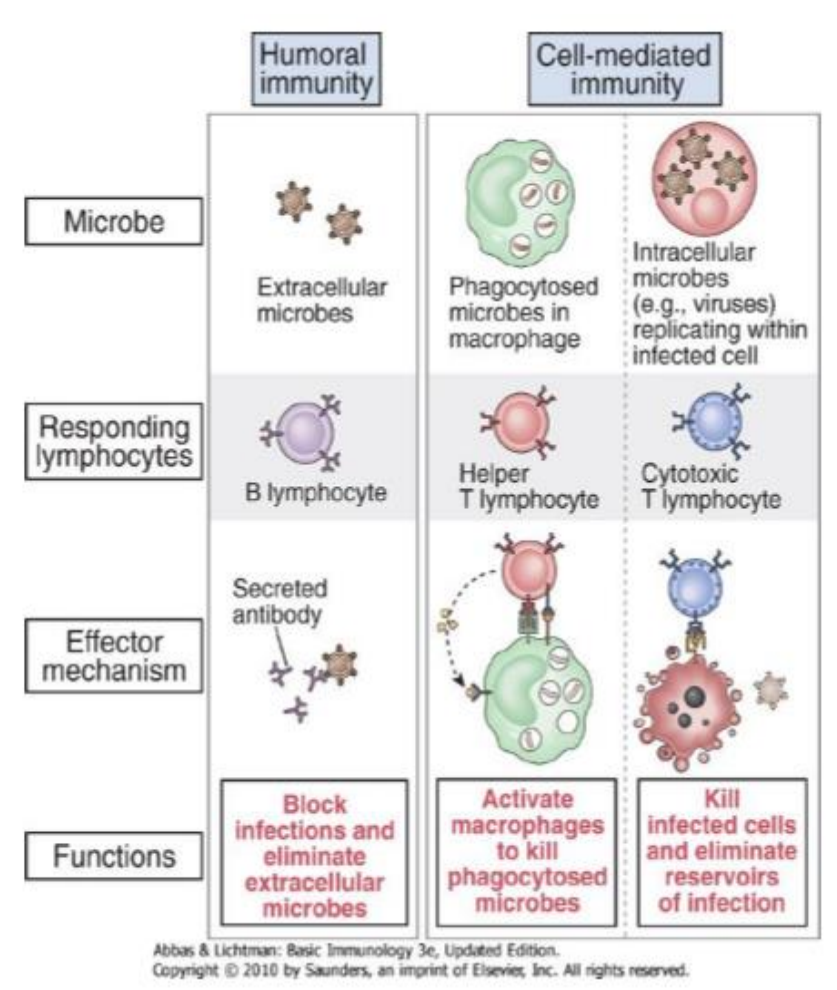

Beberapa jenis antibodi yang terdapat pada manusia diantaranya $\operatorname{IgM}, \operatorname{IgG}, \operatorname{IgD}$, IgA, dan IgE. IgM berfungsi sebagai respon awal saat terjadi infeksi, $\operatorname{IgM}$ dapat merusak antigen dan membuat komplemen terikat. IgG berfungsi sebagai respon imun sekunder, hanya IgG yang mampu menembus barrier plasenta, IgG dapat menetralkan racun dan virus, merusak antigen dan membuat komplemen terikat. IgD belum jelas fungsinya, namun muncul saat proses homeostasis. IgA terdapat pada membrane mukosa tubuh, melindungi mukosa dari toksin, virus, bakteri yang langsung bekerja menetralisasi dan mencegah pengikatan antara antigen dan antibodi di permukaan mukosa tubuh. IgE berhubungan dengan reaksi hipersensitivitas dan reaksi alergi, juga reaksi terhadap investasi parasit. ${ }^{16}$

\section{Peranan Al-qur’an dalam Meningkatkan Sistem Imunitas Manusia}

Allah Swt berfirman dalam Al-Quran surat al-A'raf: 204:

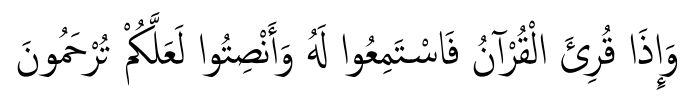

"Dan apabila dibacakan al-Qur'an, maka dengarkanlah baik-baik dan perhatikanlah dengan tenang agar kamu mendapat rahmat”.

16 Warrington et al. Allergy, Asthma \& Clinical Immunology 2011, 7 (Suppl 1):S1 http://www.aacijournal.com/content/7/S1/S1 
Banyak penelitian menyebutkan bahwa ketika al-Qur'an diperdengarkan sejak dalam kandungan maka hal tersebut bisa meningkatkan kecerdasan janin. Sampai ketika sudah dewasa pun al-Qur'an dapat meningkatkan kecerdasan baik intelektual, emosional, maupun spiritual. ${ }^{17}$

Pada studi yang dilakukan oleh Hassan dan Othman tahun 2013 tentang pengaruh mendengarkan al-Qur'an dan musik terhadap gelombang elektroensefalogram (EEG) otak didapatkan bahwa mendengarkan al-Qur'an dapat meningkatkan gelombang alfa yang artinya dapat membantu seseorang untuk lebih rileks dibandingkan dengan istirahat sambil mendengarkan musik baik lambat maupun hard rock. ${ }^{18}$

Mendengarkan al-Qur'an juga bisa membantu mengurangi kecemasan pada siswa sebelum ujian dimulai, ${ }^{19}$ kecemasan selama persalinan, ${ }^{20}$ kecemasan selama pasien dirawat di ruangan intensif, ${ }^{21}$ kecemasan sebelum pasien dilakukan tindakan invasif. $^{22}$

Tidak hanya kecerdasan saja yang bisa ditingkatkan dengan seringnya seseorang diperdengarkan al-Qur'an, namun ternyata mendengarnya pun juga dapat meningkatkan kekebalan tubuh seseorang. ${ }^{23}$

Selain meningkatkan kekebalan tubuh ketika mendengarkannya, al-Qur'an melalui seruannya kepada para para ibu untuk memberikan air susu ibu (ASI) terbukti secara ilmiah bahwa komponen sistem imun dalam ASI tidak bisa ditiru

${ }^{17}$ Suciati. 2015: The Impact of Prenatal Education Through Stimulating Qur'an's Recitation on Child Growth. Qudus International Journal of Islamic Studies. Vol 3, Issue 2.

18 Hassan \& Othman. (2013): Effects of Qur'an Listening and Music on Electroencephalogram brain wave.

${ }^{19}$ Ghorbani F, Ghorbani Z, Avazeh A. The Effect of Listening to the Holy Quran on the Level of Pre-Exam Anxiety of Secondary School Students in Zanjan City, in 2011. ZUMSJ. 2014;22:89-96. [Google Scholar]

${ }^{20}$ Jabbari B, Mirghafourvand M, Sehhatie F, Mohammad-Alizadeh-Charandabi S. The Effect of Holly Quran Voice With and Without Translation on Stress, Anxiety and Depression During Pregnancy: A Randomized Controlled Trial. J Relig Health. 2017 Epub ahead of print. [PubMed] [Google Scholar]

${ }^{21}$ Khatooni A. The effect of voice of the Holy Quran on anxiety in patients admitted to cardiac care units in a selected hospital in Tehran, 1997.[MSc thesis] School of Nursing and Midwifery, Iran University of Medical Sciences, Iran. 1997 [Google Scholar]

${ }^{22}$ Nikbakht Nasrabadi A, Jafari Gholam H, Naji H. Investigating the effect of Quranic voice on reducing anxiety before and after diagnostic and therapeutic operations in different surgical and internal surgeries of Alzahra, Kashani and Imam Hossein hospitals of Golpayegan. Teb Tazkieh. 1998;1:78-84. [Google Scholar]

${ }^{23}$ Akbar Pejhan. (2014). The Effects of Hearing Holy Quran Voice on Immune system Factors In Human. https://www.researchgate.net/publication/330010890 diakses pada tanggal 7 Oktober 2019. 


\section{Rosydina Robi'aqolbi}

oleh susu buatan pabrik manapun. ASI mengandung komponen immunoglobulin yang tinggi sehingga anak dengan ASI ekslusif dan dilanjutkan sampai dua tahun mendapatkan kekebalan tubuh lebih besar dibandingkan dengan anak yang tidak mendapatkan ASI. Penelitian secara genomic, metabolomik, proteomic, dan glikomik menunjukkan bahwa ASI memiliki peran dalam membentuk sistem imun innate. ${ }^{24}$

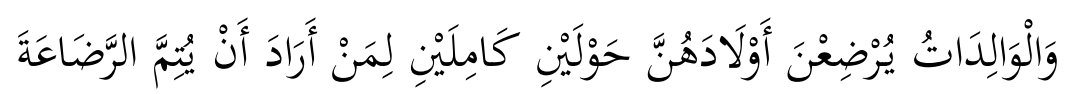

"Para ibu hendaklah menyusukan anak-anaknya selama dua tahun penuh, yaitu bagi yang ingin menyempurnakan penyusuan”. (Q.S. Al-Baqarah: 233)

Al-qur'an juga memerintahkan agar kita makan makanan sesuai dengan tuntunan, yaitu yang halal lagi baik seperti disebutkan dalam Q.S. Al-Maidah: 88 dan Q.S. Al-Baqarah: 168. Al-Qur'an juga menuntun bahwa makan dan minum tidak boleh berlebih-lebihan dalam surat Al-A'raf: 31. Anjuran tersebut juga sejalan dengan penemuan ilmiah bahwa segala zat gizi ada takarannya agar membentuk sistem kekebalan tubuh yang sempurna. Ibnu Katsir menjelaskan tafsir ayat ini:

$$
\text { قال بعض السلف :جمع الله الطبّ كله في نصف آية (وكلوا واشربوا ولا تسرفوا) }
$$

"Sebagian salaf berkata bahwa Allah telah mengumpulkan semua ilmu kedokteran pada setengah ayat ini. "25

Bahkan Nabi Muhammad Saw menjelaskan bahwa perut manusia adalah wadah yang paling buruk yang selalu diisi. Rasulullah Saw bersabda:

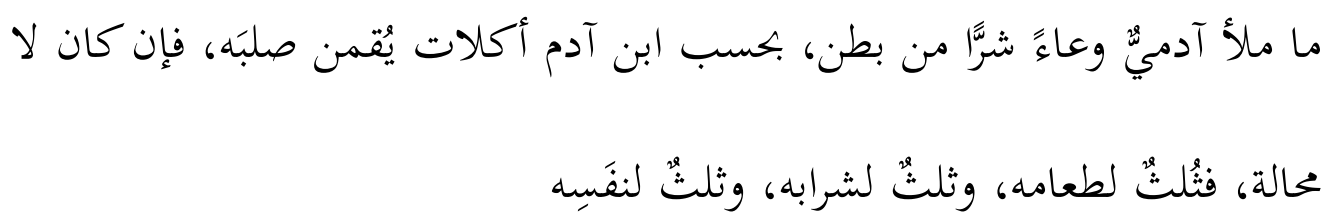

"Tidaklah anak Adam memenuhi wadah yang lebih buruk dari perut. Cukuplah bagi anak Adam memakan beberapa suapan untuk menegakkan punggungnya. Namun jika ia harus (melebihkannya), hendaknya sepertiga

${ }^{24}$ Nichole Theresa \& Robert. (2017): Innate immunity and Breast Milk. NCBI. Front Immunol. 2017; 8: 584 . Published online 2017 May 29. doi: 10.3389/fimmu.2017.00584

${ }^{25}$ Tafsir Ibnu Katsir 3/384, Dar Thaybah 
perutnya (diisi) untuk makanan, sepertiga untuk minuman dan sepertiga lagi untuk bernafas ${ }^{, 26}$

Nutrisi merupakan faktor yang sangat penting terhadap respon imun dan malnutrisi merupakan penyebab utama penyakit imunodefisiensi. Malnutrisi energi protein berhubungan dengan kegagalan mediasi sistem imun seluler, fungsi fagosit, fungsi komplemen, sekresi immunoglobulin A dan pembentukan sitokin. Kekurangan salah satu zat gizi saja sudah bisa menghasilkan respon imun yang kurang baik. Seperti kekurangan mikronutrien, di antaranya zink, selenium, besi, vitamin A, C, E, B6 dan asam folat. Sementara overnutrisi atau obesitas juga bisa mengurangi kekebalan tubuh. Bayi dengan berat lahir rendah juga memiliki gangguan sistem imun jangka panjang. ${ }^{27}$ Dengan demikian, maka aturan makan dengan porsi dan takaran yang sesuai serta zat yang halal lagi baik dianjurkan dalam Islam dan sejalan dengan temuan ilmiah.

Bahkan, Al-Qur'an memerintahkan kita untuk berpuasa.

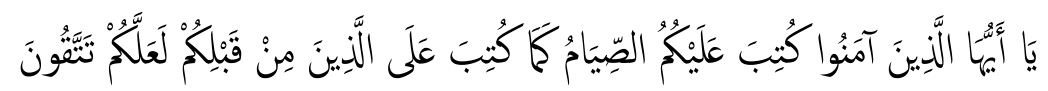

"Wahai orang-orang yang beriman, diwajibkan kepada kalian berpuasa sebagaimana diwajibkan kepada orang-orang sebelum kalian agar kalian bertakwa." (Q.S al-Baqoroh:183).

Dari penelitian yang dilakukan oleh Adawi dkk tahun 2017 menghasilkan beberapa hasil di antaranya: puasa Ramadhan mempengaruhi sistem imun, aman dilakukan pada saat kehamilan trimester kedua dan tidak berdampak negatif pada janin, memperbaiki profil lipid pada pasien jantung dan mengurangi stress oksidatif, aman dilakukan pada penderita asma dan imunodefisiensi, tidak meningkatkan marker imunologik pada penderita skizofrenia, dan adanya fluktuasi marker imunologik pada atlet muslim yang menjaga latihannya selama ramadhan. Dengan demikian, apa yang diperintahkan oleh al-Qur'an berupa

${ }^{26}$ HR At-Tirmidzi (2380), Ibnu Majah (3349), Ahmad (4/132), dan lain-lain. Hadits ini dinilai shahiholeh Al-Albani dalam As-Silsilah Ash-Shahihah (2265)

${ }^{27}$ Chandra RK. (1997): Nutrition and The Immune System: an Introduction. NCBI. Am J Clin Nutr. 66(2):460S-463S. PMID: 9250133. DOI: 10.1093/ajcn/66.2.460S. 


\section{Rosydina Robi'aqolbi}

puasa Ramadhan terbukti secara ilmiah dapat meningkatkan sistem kekebalan tubuh manusia. ${ }^{28}$

\section{Penutup dan Kesimpulan}

Sistem imun manusia merupakan sistem pertahanan tubuh dalam melawan bakteri patogen dan benda asing lainnya. Sistem imun manusia terdiri dari sistem imun innate yang muncul saat awal dan adaptive yang muncul beberapa hari setelah infeksi. Allah telah berfirman dalam Al-Qur'an bahwa manusia merupakan sebaik-baik penciptaan. Al-Qur'an juga memiliki peran dalam meningkatkan sistem imun tubuh manusia.

Sistem imun manusia merupakan sistem yang sangat sempurna penciptaannya jika kita mengetahui dengan detail bagaimana sistem imun manusia bekerja. Sebagaimana hal tersebut telah dicantumkan dalam al-Qur'an surat Adz-Dzariyat; 20-21.

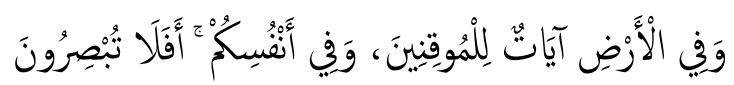

"Dan di bumi itu terdapat tanda-tanda (kekuasaan Allah) bagi orang-orang yang yakin. Dan (juga) pada dirimu sendiri. Maka apakah kamu tidak memperhatikan?" (Adz-Dzariyat: 20-21)

\section{Daftar Pustaka}

\section{Al-Qur'anul Karim}

Abbas, Abul K., Andrew Lichtman. Basic Immunology, Function and Disorders of Immune System $3^{\text {rd }}$ Edition. Saunders, an imprint of Elsevier Inc. 2011.

Adawi, et al. Ramadan Fasting Exerts Immunomodulatory Effects: Insights from a Systematic Review. NCBI. Front Immunol. 2017; 8: 1144. Published online 2017 Nov 27, 2017.

Bailey, M. The immune system: differences between man, pigs, ruminants and mice. Front. Immunol. Conference Abstract: ECMIS - E. coli and the

${ }^{28}$ Adawi, et al., (2017): Ramadan Fasting Exerts Immunomodulatory Effects: Insights from a Systematic Review. NCBI. Front Immunol. 2017; 8: 1144. Published online 2017 Nov 27. doi: 10.3389/fimmu.2017.01144 
Mucosal Immune System: Interaction, Modulation and Vaccination. 2011. doi: 10.3389/conf.fimmu.2011.01.00003.

Chaplin, David D. Overview of the Immune Response. J Allergy Clin Immunology., 125, 2010, 3-23.

Chandra RK. Nutrition and The Immune System: an Introduction. NCBI. Am J Clin Nutr. 66(2), 1997, 460S-463S. PMID: 9250133. DOI: 10.1093/ajcn/66.2.460S.

Durrant, W. E. and Dong, X. Systemic Acquired Resistance. Annu. rev. Phytopathol. 42, 2004, 185-209.

Ganna, Karnen, Iris R. Imunologi Dasar, edisi 3, Jakarta: Balal Penerbit FKUI, 1996.

Ghorbani F, Ghorbani Z, Avazeh A. The Effect of Listening to the Holy Quran on the Level of Pre-Exam Anxiety of Secondary School Students in Zanjan City, in 2011. ZUMSJ. 2014;22:89-96. [Google Scholar].

Hassan \& Othman. Effects of Qur'an Listening and Music on Electroencephalogram brain wave. 2013.

Jabbari B, Mirghafourvand M, Sehhatie F, Mohammad-Alizadeh-Charandabi S. The Effect of Holly Quran Voice With and Without Translation on Stress, Anxiety and Depression During Pregnancy: A Randomized Controlled Trial. J Relig Health. 2017 Epub ahead of print. [PubMed] [Google Scholar].

Khatooni A. The effect of voice of the Holy Quran on anxiety in patients admitted to cardiac care units in a selected hospital in Tehran, 1997.[MSc thesis] School of Nursing and Midwifery, Iran University of Medical Sciences, Iran. 1997 [Google Scholar].

L.Kiraly, dkk. Similarities and Differences in Plant and Animal Immune Systems - What is Inhibiting Pathogen? Acta Phytopathologica at Entomologica Hungarica 48 (2), 2013, 187-205.

Maekawa, t., Kufer, t. A. and schulze-Lefert, P. nLr functions in plant and animal immune systems: so far and yet so close. Nature Immunol. 12, 2011, 818826. 


\section{Rosydina Robi'aqolbi}

Mestas, Javier and Christopher C. W. Hughes. Of Mice and Not Men: Differences between. J Immunol (172), 2004, 2731-2738.

Murphy, Kenneth, Paul Travers, and Mark Walport. Janeway's Immunobiology $7^{\text {th }}$ ed. Garland Science, New York, NY, 2008.

Nichole Theresa \& Robert. Innate immunity and Breast Milk. NCBI. Front Immunol. 2017; 8: 584. Published online 2017 May 29. doi: 10.3389/fimmu.2017.00584.

Nikbakht Nasrabadi A, Jafari Gholam H, Naji H. Investigating the effect of Quranic voice on reducing anxiety before and after diagnostic and therapeutic operations in different surgical and internal surgeries of Alzahra, Kashani and Imam Hossein hospitals of Golpayegan. Teb Tazkieh. 1998; 1:78-84. [Google Scholar].

Pejhan, Akbar. The Effects of Hearing Holy Quran Voice on Immune system Factors In Human. 2014. https://www.researchgate.net/publication/ 330010890 diakses pada tanggal 7 Oktober 2019.

Rifa'i (ar), Nasib. Ringkasan Tafsir Ibnu Katsir Jilid 4. Jakarta: Gema Insani, 2012,768 .

Ross, A. F. systemic acquired resistance induced by localized virus infections in plants. Virology 14, 340-358.

Saifudin, dkk. Islam, Sains, dan Kesehatan: Metode Islam dan Sains dalam Mengungkap Kebenaran. Yogyakarta: Pustaka Muslim, 2016, 103-107.

Suciati. The Impact of Prenatal Education Through Stimulating Qur'an's Recitation on Child Growth. Qudus International Journal of Islamic Studies. Vol 3, Issue 2. 2015.

Tafsir Ibnu Katsir 3/384. Dar Thaybah, t.t.

Warrington et al. Allergy, Asthma \& Clinical Immunology 2011, 7 (Suppl 1):S1 http://www.aacijournal.com/content/7/S1/S1

HR At-Tirmidzi (2380), Ibnu Majah (3349), Ahmad (4/132), dan lain-lain. Hadits ini dinilai shahih oleh Al-Albani dalam As-Silsilah Ash-Shahihah (2265).

Khadan. Al Razi, Smallpox and Measles. http://www.muslimheritage. com/article/al-raz-smallpox-and-measles, 2016. (diakses 3 Oktober 2019). 
Tafsir Al-Mukhtashar/Markaz Tafsir di bawah pengawasan Syaikh Dr. Shalih bin Abdullah bin Humaid, Imam Masjidil Haram https://tafsirweb.com/12853surat-at-tin-ayat-4.html diakses pada tanggal 3 Oktober 1989. 